\title{
減速機の摩擦を考慮した位置制御系の散逸エネルギー最小化*
}

$$
\text { 朱 一 庭*1, 泉 照之 }{ }^{* 2} \text {, 周 海*2 }
$$

\section{Minimization of Dissipated Energy in Position Control System Considering the Friction of Gears}

\author{
Yiting ZHU, Teruyuki IZUMI*3 and Hai ZHOU \\ ${ }^{* 3}$ Department of Electronic and Control Systems Engineering, Shimane University, \\ 1060 Nishi-Kawatsu-cho, Matsue-shi, Shimane, 690-8504 Japan
}

\begin{abstract}
This paper discusses on optimal current and velocity functions which minimize the dissipated energy of a servo system with a reduction gear train. Coulomb friction of the gears is represented by the efficiency of the gears and assumed to be proportional to the absolute value of the current of a motor. The optimal functions can be obtained from an optimal control theory by introducing a zero cross time $t_{c}$, when the current is changed from positive to negative. As the dissipated energy can be given as a function of $t_{c}$, the optimal zero cross time $t_{c}{ }^{*}$ minimizing the energy can be represented by a simple function of the efficiency of the gears. This method is expanded into the case including the viscous friction in addition to the Coulomb friction. The influence of the viscous frictional coefficient upon the optimal zero cross time $t_{c}{ }^{*}$ is examined by simulations. The expression of the Coulomb and the viscous frictions is verified by experiments using planetary gears with a DC motor.
\end{abstract}

Key Words: Position Control, Minimum Energy, Optimal Velocity Function, Reduction Gear, Coulomb Friction, Efficiency

\section{1. まえがき}

ロボットや携帯用カメラなどメカトロニクス機器で は, アクチュエータとしてモータが多く使用されてい る. モータで高トルクを発生させる場合, 大電流を流 す必要があるのでモー夕は大型となる. したがって, 小型モータで高トルクを得るには減速機が必要である. 減速機は, 摩摖を伴うので, 機械損を増加させる.この 損失は, 大型のメカトロニクス機器では無駄なエネル ギーを浪費することになり, 機器の省エネルギー化に 逆行する. また, 携帯機器や歩行ロボットなどでは電 池の蓄電量を短期間に消耗させる欠点につながる．減 速機の減速比の選定については, モ一タから負荷への トルク伝達を最大にするイナーシャマッチング法が知 られている(1). また, モータの容量を最小にするモ一 夕や減速機を選定する方法も提案され，その消費エネ ルギーが検討されている(2).一方, 位置制御において 消費エネルギーを少なくする動かし方の研究もある(3) (4) (5).これらは, 従来台形の速度関数が多く用いられ ているのに対して, モータのジュール熱損と摩擦熱損 を最小にする速度関数を決める研究である. しかし，

* 原稿受付 2005 年 10 月 7 日.

*1 島根大学総合理工学部 (亚690-8504 松江市西川津町 1060).

*2 正員. 島根大学総合理工学部.

E-mail : izumi @ riko.shimane u.ac.jp
減速機内の歯車のクーロン摩擦と粘性摩擦が考慮され ていない.

本論文は，始動・停止を繰り返すサーボ系が減速機 を含む場合の散逸エネルギーを考え，それを最小にす る最適な電流関数や速度関数を求める. まず, 減速機 に含まれるクーロン摩擦力を減速機の効率を用いて表 わし，それがモー夕電流の絶対值に比例するとして駆 動系の運動方程式を作った. そして，決められた動作 時間で目標角度に達するために散逸されるエネルギー を考え，それを最小化するために最適制御理論を用い た. その理論は, クーロン摩擦による駆動系の非線形 性のために，そのまま適用できない。そこで, 電流が 正から負に切り替わる零交差時間を導入した. そして, 散逸エネルギーが零交差時間の関数になることを導き, それを最小にする最適な零交差時間が減速機の効率に 関する簡単な関数になることを示している.さらに， 高速回転時の粘性摩摖が散逸エネルギーに及ぼす影響 を考え，最適な零交差時間の求め方も示している.

\section{2. 運動方程式と散逸エネルギー}

モータの動力を減速機で伝達するときの運動方程式 と散逸エネルギーを求める. モ一タの入力電流を $i(t)$, トルク定数を $K$, 減速機の減速比を $n$, 出力軸の角速 
度を $\dot{\theta}(t)$ とする.

2.1 減速機の効率とクーロン摩擦力 減速機の 摩擦力は, 速度に比例する粘性摩摖と速度に無関係な クーロン摩擦に大別できる. 減速機の効率としてクー ロン摩擦による損失のみから定義される場合が多い( ${ }^{(6)}$ ので, 本論文でもそれに従う. 減速機の出力軸からみ たクーロン摩擦トルクを $F_{c}$ とすると, 減速機の動力 損失は $F_{c} \times \dot{\theta}$ となる. 入力軸の動力は $K i \times n \dot{\theta}$ である ので, 減速機の動力伝達効率 $\eta$ は

$$
\eta \triangleq \frac{n K i \dot{\theta}-F_{c} \dot{\theta}}{K i n \dot{\theta}}=1-\frac{F_{c}}{n K i}
$$

となる.この式よりクーロン摩擦トルクは, $F_{c}=$ $(1-\eta) n K i$ となり, 効率とモー夕の入力電流を用いて 表される. 角度制御系において, 指令が与えられて最 終角度に至る過程では, 回転方向は基本的には変わら ない. したがって, クーロン摩摖トルクは, その方向 が回転方向と常に逆であるので, 電流の正負に関係な く一定方向であり，つぎのように表される.

$$
F_{c}=(1-\eta) n K|i|
$$

この式は, クーロン摩擦トルクが伝達トルクの絶対值 すなわち歯車のかみ合い力に比例することを意味する.

2.2 運動方程式と散逸エネルギー 減速機の出 力軸から見た系全体の慣性モーメントを $H$ とする. ま た, 潤滑剤による粘性摩擦係数を $F_{l}$ とする. この場 合, クーロン摩擦トルクが式 (2) より電流の絶対値に 比例するので, 駆動系の運動方程式はつぎのように表 される.

$$
H \ddot{\theta}(t)+(1-\eta) n K|i(t)|+F_{l} \dot{\theta}(t)=n K i(t)
$$

この駆動系で発生する摩擦熱は, 両摩擦トルクに角速 度を掛けて求められる. 一方, モ一夕の電機子では抵 抗 $R$ によるジュール熱が発生する. したがって, 駆動 部で散逸されるエネルギーは, 次式のようになる.

$$
J=\int_{0}^{t_{f}}\left[R i(t)^{2}+\left\{(1-\eta) n K|i(t)|+F_{l} \dot{\theta}(t)\right) \dot{\theta}(t)\right] d t
$$

ここで, 動作は初期時刻 $t=0$ から最終時刻 $t_{f}$ までと している. 角度制御系を考えているので, これらの時 刻における角度と角速度の境界条件はそれぞれつぎの ように指定される.

$$
\begin{aligned}
\theta(0) & =\theta_{0} & \dot{\theta}(0) & =0 \\
\theta\left(t_{f}\right) & =\theta_{f} & \dot{\theta}\left(t_{f}\right) & =0
\end{aligned}
$$

以下に, これらの境界条件を満たし, 式 (4)を最小に する最適な角速度関数や電流関数を求める.

\section{3. 最適角速度関数の一般解}

運動方程式は式 (3) からわかるように電流の絶対値 に依存する. 電流は制御過程で符号が変るので, 電流 が正および負のそれぞれの条件において最適な角速度 関数の一般解を求める.

3 -1 電流が正の場合 電流 $i(t)$ が正の場合, 運 動方程式 (3) はつぎのようになる.

$$
H \ddot{\theta}(t)+F_{l} \dot{\theta}(t)=\eta n K i(t)
$$

角度 $\theta(t)$ を $x_{1}(t)$, 角速度 $\dot{\theta}(t)$ を $x_{2}(t)$ として, 式 (7) を 状態方程式に書き換えて, 随伴変数 $p_{1}(t), p_{2}(t)$ を用 いると, ハミルトニアン $H_{a}$ はつぎのようになる(7).

$$
\begin{aligned}
H_{a}= & -R i(t)^{2}-(1-\eta) n K i(t) x_{2}(t)-F_{l} x_{2}(t)^{2} \\
& +p_{1}(t) x_{2}(t)+p_{2}(t) H^{-1}\left(-F_{l} x_{2}(t)+\eta n K i(t)\right)
\end{aligned}
$$

これから $\dot{x}_{1}(t)=\partial H_{a} / \partial p_{1}, \dot{x}_{2}(t)=\partial H_{a} / \partial p_{2}, \dot{p}_{1}(t)=$ $-\partial H_{a} / \partial x_{1}, \dot{p}_{2}(t)=-\partial H_{a} / \partial x_{2}$ を求めると, Euler の規 準方程式

$$
\begin{aligned}
& \dot{x}_{1}(t)=x_{2}(t) \\
& \dot{x}_{2}(t)=H^{-1}\left(-F_{l} x_{2}(t)+\eta n K i(t)\right) \\
& \dot{p}_{1}(t)=0 \\
& \dot{p}_{2}(t)=(1-\eta) n K i(t)+2 F_{l} x_{2}(t)+H^{-1} F_{l} p_{2}(t)-p_{1}(t)
\end{aligned}
$$

が得られる. また, $\partial H_{a} / \partial i=0$ より, 最適電流は次式 のようになる.

$$
i(t)=(2 R)^{-1}\left\{H^{-1} \eta n K p_{2}(t)-(1-\eta) n K x_{2}(t)\right\}
$$

式 (8)〜(11) は, 式 (12) が代入されると, 4 元連立同 次微分方程式となる. しかし, 式 (10) が積分定数 $c_{1}$ を用いて $p_{1}(t)=-c_{1}$ と単独に解かれるので, Euler の 規準方程式は, つぎのように $p_{2}(t)$ と $x_{2}(t)$ の 2 変数だ けを用いた式に変換できる.

$$
\left.\begin{array}{l}
\dot{x}_{2}(t)=-a_{1} x_{2}(t)+a_{2} p_{2}(t) \\
\dot{p}_{2}(t)=a_{3} x_{2}(t)+a_{1} p_{2}(t)+c_{1}
\end{array}\right\}
$$

ここで, 定数 $a_{1}, a_{2}, a_{3}$ は以下のとおりである.

$$
\begin{aligned}
& a_{1}=H^{-1}\left\{F_{l}+(2 R)^{-1} \eta(1-\eta)(n K)^{2}\right\} \\
& a_{2}=(2 R)^{-1}\left(H^{-1} \eta n K\right)^{2} \\
& a_{3}=2 F_{l}-(2 R)^{-1}(1-\eta)^{2}(n K)^{2}
\end{aligned}
$$

さらに, 式(13)の $p_{2}(t)$ を消去すると, つぎのように $x_{2}(t)$ だけを含む簡単な微分方程式になる.

$$
\ddot{x}_{2}(t)-\left(a_{1}{ }^{2}+a_{2} a_{3}\right) x_{2}(t)=a_{2} c_{1}
$$


左辺第 2 項の係数を

$$
\alpha^{2}=a_{1}^{2}+a_{2} a_{3}=H^{-2} F_{l}\left\{F_{l}+R^{-1} \eta(n K)^{2}\right\}
$$

と置くと, 式(14)の一般解は任意定数 $q_{1}, q_{2}$ を用いて

$$
x_{2 a}(t)=q_{1} e^{\alpha t}+q_{2} e^{-\alpha t}-\frac{a_{2} c_{1}}{\alpha^{2}}
$$

となる. 添字 $a$ を付けたこの $x_{2 a}(t)$ は, 電流が正であ るときの最適角速度関数である.

もし, $F_{l}=0$ のとき, 式 (15) より $\alpha^{2}=0$ となるの で, 式 (14) はつぎのように非常に簡単な式になる.

$$
\ddot{x}_{2}(t)=a_{2} c_{1}
$$

この式の一般解は積分定数 $c_{2}, c_{3}$ を用いて

$$
x_{2 a}(t)=a_{2} c_{1} t^{2} / 2+c_{2} t+c_{3}
$$

と表される.したがって, 粘性摩擦が無視できる場合, 最適角速度関数 $x_{2 a}(t)$ は 2 次関数になる.

3.2 電流が負の場合 電流 $i(t)$ が負の場合, 運 動方程式 (3) はつぎのようになる.

$$
H \ddot{\theta}(t)+F_{l} \dot{\theta}(t)=(2-\eta) n K i(t)
$$

前節と同様に Euler の規準方程式を導き， $p_{1}(t)=-d_{1}$ と置いて, 整理すると次式が得られる.

$$
\ddot{x}_{2}(t)-\left(b_{1}{ }^{2}+b_{2} b_{3}\right) x_{2}(t)=b_{2} d_{1}
$$

ここで, 定数 $b_{1}, b_{2}, b_{3}$ は以下に示される.

$$
\begin{aligned}
& b_{1}=H^{-1}\left\{F_{l}-(2 R)^{-1}(2-\eta)(1-\eta)(n K)^{2}\right\} \\
& b_{2}=(2 R)^{-1}\left\{H^{-1}(2-\eta) n K\right\}^{2} \\
& b_{3}=2 F_{l}-(2 R)^{-1}(1-\eta)^{2}(n K)^{2}
\end{aligned}
$$

\section{これらから得られた}

$$
\beta^{2}=b_{1}^{2}+b_{2} b_{3}=H^{-2} F_{l}\left\{F_{l}+R^{-1}(2-\eta)(n K)^{2}\right\}
$$

を用いると, 式 (20)の一般解は任意定数 $r_{1}, r_{2}$ を用い てつぎのように表される.

$$
x_{2 b}(t)=r_{1} e^{\beta t}+r_{2} e^{-\beta t}-\frac{b_{2} d_{1}}{\beta^{2}}
$$

この $x_{2 b}(t)$ が負電流における最適角速度関数である.

もし, $F_{l}=0$ のとき, 式 (21) より $\beta=0$ となるの で, 式 $(20)$ は $\ddot{x}_{2}(t)=b_{2} d_{1}$ となる. したがって, 電流 が負の場合の最適角速度関数 $x_{2 b}(t)$ も, 正の場合と同 様につぎのように 2 次関数となる.

$$
x_{2 b}(t)=b_{2} d_{1} t^{2} / 2+d_{2} t+d_{3}
$$

\section{4. 低速回転}

角度制御において減速機を駆動するモー夕の電流は, 一般性を失うことなく正から始まり負で終わると仮定 できる. 本論文では, 電流が正の期間を前期, 負の期 間を後期と称し, 正から負に変わる零交差時間 $t_{c}$ を仮 定する，そして， $t_{c}$ における境界条件を満たす最適な 角速度関数や電流関数を求め, 散逸エネルギーが $t_{c}$ の 関数になることを示し，散逸エネルギーを最小にする 最適な零交差時間 $t_{c}{ }^{*}$ を求める.

本章は角度制御が比較的低速回転で実現される場合 を考える.したがって, 粘性摩擦力が無視できるので, 角速度関数として電流が正の場合式 (18) を, 電流が負 の場合式 (23) をそれぞれ用い, それらの未定定数を決 める.

\section{1 最適角速度関数の係数}

4.1.1 初期・最終速度条件を満たす $c_{3}, d_{3}$ 式 (5) より初期速度が 0 であるので, 式(18)の $c_{3}$ は 0 と 決まる. したがって, 前期の角速度関数は, 次式のよ うに未定定数 $c_{1}, c_{2}$ だけを含む関数になる.

$$
x_{2 a}(t)=a_{2} c_{1} t^{2} / 2+c_{2} t
$$

一方, 式(6)より最終速度も0であるから, 式 (23) は $x_{2 b}\left(t_{f}\right)=0$ となるので, $d_{3}$ は $-b_{2} d_{1} t_{f}^{2} / 2-d_{2} t_{f}$ と決め られる. この值を式 (23) に代入すると, 後期の角速度 関数 $x_{2 b}(t)$ は,

$$
x_{2 b}(t)=b_{2} d_{1}\left(t^{2}-t_{f}\right)^{2} / 2+d_{2}\left(t-t_{f}\right)
$$

のように未定定数 $d_{1}, d_{2}$ だけを含む関数になる.

4.1.2 電流の連続性を満たす $c_{2}, d_{2}$ 電流が正 から負に切り替わる零交差時間 $t_{c}$ に注目する. その瞬 間の電流值は電流の連続性より 0 となるので, $F_{l}=0$ とした式 (9) より角加速度も0になる. したがって, 前期の角加速度関数が $\dot{x}_{2 a}(t)=a_{2} c_{1} t+c_{2}$ であるので, $\dot{x}_{2 a}\left(t_{c}\right)=0$ より, $c_{2}$ は次式のように $c_{1}$ で表せる.

$$
c_{2}=-t_{c} a_{2} c_{1}
$$

同様に, 後期の角加速度関数が $\dot{x}_{2 b}(t)=b_{2} d_{1} t+d_{2}$ と 表されるので, $\dot{x}_{2 b}\left(t_{c}\right)=0$ より, $d_{2}$ は

$$
d_{2}=-t_{c} b_{2} d_{1}
$$

と $d_{1}$ で表せる. 以上, $c_{2}, d_{2}$ がそれぞれ $c_{1}, d_{1}$ より決 定されることが分かる.

4.1.3 $c_{1}$ と $d_{1}$ の関係 式 (24) に式 (26) を代入 すると, 前期の $t=t_{c}$ における角速度は

$$
x_{2 a}\left(t_{c}\right)=-t_{c}{ }^{2} a_{2} c_{1} / 2
$$


となる. 同様に式 (25) に式 (27) を代入して, 後期の $t=t_{c}$ における角速度を求めるとつぎのようになる.

$$
x_{2 b}\left(t_{c}\right)=-\left(t_{f}-t_{c}\right)^{2} b_{2} d_{1} / 2
$$

$t=t_{c}$ において角速度関数は連続しているので, $x_{2 a}\left(t_{c}\right)=x_{2 b}\left(t_{c}\right)$ が成立する. したがって, 式 (28),(29) より $d_{1}$ が $c_{1}$ で次のように表される.

$$
d_{1}=\frac{a_{2}}{b_{2}}\left(\frac{t_{c}}{t_{f}-t_{c}}\right)^{2} c_{1}
$$

4.1.4 角度条件から $c_{1}$ の決定 未定定数 $c_{2}, d_{1}, d_{2}$ は $c_{1}$ のみで表現できるようになった.こ の $c_{1}$ を含んだ角速度関数を積分して, 式 (5),(6)の角 度の境界条件を満たす式

$$
\int_{0}^{t_{c}} x_{2 a}(t) d t+\int_{t_{c}}^{t_{f}} x_{2 b}(t) d t=\theta_{f}-\theta_{0}
$$

より， $c_{1}$ が次式のように決定できる.

$$
c_{1}=-\frac{3}{t_{f}} \frac{1}{a_{2} t_{c}^{2}}\left(\theta_{f}-\theta_{0}\right)
$$

以上のことより全ての未定定数が決められたので, 最 適角速度関数は式 (18),(23) から次のように表される.

$$
\begin{cases}x_{2 a}(t)=\frac{3}{2 t_{f}}\left\{1-\frac{\left(t-t_{c}\right)^{2}}{t_{c}{ }^{2}}\right\}\left(\theta_{f}-\theta_{0}\right) & \left(0 \leq t \leq t_{c}\right) \\ x_{2 b}(t)=\frac{3}{2 t_{f}}\left\{1-\frac{\left(t-t_{c}\right)^{2}}{\left(t_{f}-t_{c}\right)^{2}}\right\}\left(\theta_{f}-\theta_{0}\right) & \left(t_{c} \leq t \leq t_{f}\right)\end{cases}
$$

4.2 最適電流関数と損失 前・後期の最適な電 流関数は, 式 (33) から得られた角加速度関数を $F_{l}=0$ とした式 (7) および式 (19)にそれぞれ代入して, つぎ のように求められる.

$$
\left\{\begin{array}{r}
i_{a}(t)=\frac{3}{t_{f}} \frac{H}{\eta n K} \frac{-t+t_{c}}{t_{c}{ }^{2}}\left(\theta_{f}-\theta_{0}\right) \\
i_{b}(t)=\frac{3}{t_{f}} \frac{H}{(2-\eta) n K} \frac{-t+t_{c}}{\left(t_{c}-t_{f}\right)^{2}}\left(\theta_{f}-\theta_{0}\right) \\
\left(t_{c} \leq t \leq t_{f}\right)
\end{array}\right.
$$

この電流の式を式 (4) の第 1 項目に代入して前・後期 のジュール熱をそれぞれ計算すると，全ジュール熱 $J_{R}$ は, つぎのように $t_{c}$ の関数で表される.

$$
J_{R}=\frac{3}{t_{f}^{2}}\left\{\frac{1}{t_{c} \eta^{2}}+\frac{1}{\left(t_{f}-t_{c}\right)(2-\eta)^{2}}\right\} \frac{H^{2} R}{(n K)^{2}}\left(\theta_{f}-\theta_{0}\right)^{2}
$$

一方, クーロン摩摖による損失 $J_{C}$ は, 式 (33) と式 (34) を $F_{l}=0$ とした式 (4)の第 2 項目に代入して, 積分す れば, つぎのようになる.

$$
J_{C}=\frac{9}{4 t_{f}^{2}} \frac{1-\eta}{\eta(2-\eta)} H\left(\theta_{f}-\theta_{0}\right)^{2}
$$

この式は, クーロン摩擦による損失が零交差時間 $t_{c}$ に 無関係であることを示す.
4.3 最適な零交差時間 $\quad J_{C}$ は $t_{c}$ に関係しない ので, 散逸エネルギーを最小にする最適な零交差時間 $t_{c}{ }^{*}$ は, 全ジュール熱 $J_{R}$ のみに依存する. 式 (35) を $t_{c}$ で微分すれば,

$$
\frac{\partial J_{R}}{\partial t_{c}}=\frac{3}{t_{f}^{2}}\left\{\frac{1}{\left(t_{f}-t_{c}\right)^{2}(2-\eta)^{2}}-\frac{1}{t_{c}^{2} \eta^{2}}\right\} \frac{H^{2} R}{(n K)^{2}}\left(\theta_{f}-\theta_{0}\right)^{2}
$$

が得られ,これが零となる式より，次式が導かれる.

$$
t_{c}^{*}=\frac{t_{f}}{2}(2-\eta)
$$

以上, 最適な零交差時間 $t_{c}{ }^{*}$ は減速機の効率 $\eta$ を用い た簡潔な式で表現できた.この $t_{c}{ }^{*}$ を式 (35) に代入し て求めた最小ジュール熱と, 式 (36)のクーロン摩擦熱 を合わせることによって, 散逸エネルギーの最小值が つぎのように表される.

$$
\begin{aligned}
J=\frac{12}{t_{f}^{3}} \frac{H^{2} R}{(n K)^{2}} \frac{1}{\eta^{2}(2-\eta)^{2}}\left(\theta_{f}-\theta_{0}\right)^{2} \\
+\frac{9}{4 t_{f}{ }^{2}} H \frac{1-\eta}{\eta(2-\eta)}\left(\theta_{f}-\theta_{0}\right)^{2}
\end{aligned}
$$

\section{5. 粘性摩摖力の考慮}

粘性摩擦トルクは角速度に比例するので高速回転時 には無視できない。したがって, 前・後期の角速度関 数 $x_{2 a}(t), x_{2 b}(t)$ として, それぞれ式 (16),(22) を用いな ければならない，前章と同様に,これらの式の未定定 数を境界条件から決めて, 最適な角速度関数や電流関 数を求める.

\section{1 最適角速度関数}

5.1.1 初期・最終速度を満たす条件式(16)の 係数 $c_{1}$ は, 初期速度の条件より, $\left(q_{1}+q_{2}\right) \alpha^{2} / a_{2}$ と決 まる. したがって, 前期の角速度関数は,

$$
x_{2 a}(t)=q_{1}\left(e^{\alpha t}-1\right)+q_{2}\left(e^{-\alpha t}-1\right)
$$

と末定定数 $q_{1}, q_{2}$ だけを含む関数になる.一方, 最終 速度の条件より式 (22) は $x_{2 b}\left(t_{f}\right)=0$ となるので, 係 数 $d_{1}$ は $\left(r_{1} e^{\beta t_{f}}+r_{2} e^{-\beta t_{f}}\right) \beta^{2} / b_{2}$ と決められる.この式 を式 (22) に代入すると, 後期の角速度関数 $x_{2 b}(t)$ も, つぎのように末定定数 $r_{1}, r_{2}$ のみで表される.

$$
x_{2 b}(t)=r_{1}\left(e^{\beta t}-e^{\beta t_{f}}\right)+r_{2}\left(e^{-\beta t}-e^{-\beta t_{f}}\right)
$$

5.1.2 電流の連続性を満たす条件零交差時間 $t_{c}$ において, 電流の連続性より $i\left(t_{c}\right)=0$ となるので, 式(9)より $H \dot{x}_{2 a}\left(t_{c}\right)+F_{l} x_{2 a}\left(t_{c}\right)=0$ が成立する.これに 前期の角速度 $x_{2 a}\left(t_{c}\right)$ と角加速度 $\dot{x}_{2 a}\left(t_{c}\right)$ を代入すると

$$
\begin{aligned}
& H\left(q_{1} \alpha e^{\alpha t_{c}}-q_{2} \alpha e^{-\alpha t_{c}}\right) \\
& \quad+F_{l}\left\{q_{1}\left(e^{\alpha t_{c}}-1\right)+q_{2}\left(e^{-\alpha t_{c}}-1\right)\right\}=0
\end{aligned}
$$


が得られる.したがって， $q_{2}$ は次式のように $q_{1}$ で表 される.

$$
q_{2}=q_{1} \frac{H \alpha e^{\alpha t_{c}}+F_{l}\left(e^{\alpha t_{c}}-1\right)}{H \alpha+F_{l}\left(e^{\alpha t_{c}}-1\right)} e^{\alpha t_{c}}
$$

後期の開始時刻 $t=t_{c}$ において電流は同様に 0 となる. したがって, 式 (19)より $H \dot{x}_{2 b}\left(t_{c}\right)+F_{l} x_{2 b}\left(t_{c}\right)=0$ とな るので, $r_{2}$ は次式のように $r_{1}$ で表せる.

$$
r_{2}=r_{1} \frac{H \beta e^{\beta t_{c}}+F_{l}\left(e^{\beta t_{c}}-e^{\beta t_{f}}\right)}{H \beta e^{\beta t_{f}}+F_{l}\left(e^{\beta t_{c}}-e^{\beta t_{f}}\right)} e^{\left.\beta t_{c}+t_{f}\right)}
$$

5.1.3 速度の連続性を満たす条件＼cjkstart式(40)に式 (43) を代入すると, 前期の $t=t_{c}$ における角速度は

$$
x_{2 a}\left(t_{c}\right)=-\frac{H \alpha\left(e^{\alpha t_{c}}-1\right)^{2}}{H \alpha+F_{l}\left(e^{\alpha t_{c}}-1\right)} q_{1}
$$

となる. 同様に式 (41) に式 (44) を代入して, $t=t_{c}$ 時 の後期の角速度を求めるとつぎのように表される.

$$
x_{2 b}\left(t_{c}\right)=-\frac{H \beta\left(e^{\beta t_{c}}-e^{\beta t_{f}}\right)^{2}}{H \beta e^{\beta t_{f}}+F_{l}\left(e^{\beta t_{c}}-e^{\beta t_{f}}\right)} r_{1}
$$

速度の連続性 $x_{2 a}\left(t_{c}\right)=x_{2 b}\left(t_{c}\right)$ より, $r_{1}$ が $q_{1}$ で次のよ うに表現できる.

$$
r_{1}=q_{1} \frac{\alpha\left(e^{\alpha t_{c}}-1\right)^{2}\left\{H \beta e^{\beta t_{f}}+F_{l}\left(e^{\beta t_{c}}-e^{\beta t_{f}}\right)\right\}}{\beta\left(e^{\beta t_{c}}-e^{\beta t_{f}}\right)^{2}\left\{H \alpha+F_{l}\left(e^{\alpha t_{c}}-1\right)\right\}}
$$

5.1.4 角度を満たす条件 $q_{2}, r_{1}, r_{2}$ は $q_{1}$ のみ の関数であるので, 式(31) を計算して整理すると, $q_{1}$ が次式のように決定できる.

$$
q_{1}=\frac{\alpha \beta^{2}\left(e^{\beta t_{c}}-e^{\beta t_{f}}\right)^{2}\left\{H \alpha+F_{l}\left(e^{\alpha t_{c}}-1\right)\right\}}{D\left(t_{c}\right)}\left(\theta_{f}-\theta_{0}\right)
$$

ここで, 分母 $D$ は $t_{c}$ の関数で, 以下のようになる.

$$
\begin{gathered}
D\left(t_{c}\right)=2\left[\beta ^ { 2 } ( e ^ { \beta t _ { c } } - e ^ { \beta t _ { f } } ) ^ { 2 } e ^ { \alpha t _ { c } } \left\{\alpha\left(H-F_{l} t_{c}\right) \sinh \left(\alpha t_{c}\right)\right.\right. \\
\left.+\left(2 F_{l}-H \alpha^{2} t_{c}\right) \cosh \left(\alpha t_{c}\right)-2 F_{l}\right\} \\
-\alpha^{2}\left(e^{\alpha t_{c}}-1\right)^{2} e^{\left.\beta t_{c}+t_{f}\right)} \\
\left\{\beta\left(H-F_{l}\left(t_{c}-t_{f}\right)\right) \sinh \left(\beta\left(t_{c}-t_{f}\right)\right)\right. \\
\left.\left.+\left(2 F_{l}-H \beta^{2}\left(t_{c}-t_{f}\right)\right) \cosh \left(\beta\left(t_{c}-t_{f}\right)\right)-2 F_{l}\right\}\right]
\end{gathered}
$$

式(48)より $q_{1}$ が決定できたので, 式(47)より $r_{1}$ が, 続いて式(44)より $r_{2}$ が, また, 式(43)より $q_{2}$ がそれ ぞれ決められる.これらを式 (40) と式 (41) に代入する ことにより最適角速度関数が $t_{c}$ の関数として求められ たことになる.

5.2 最適な電流関数と零交差時間前・後期の 最適な電流関数は, 前節で得られた角速度関数を式 (7)
および式 (19)にそれぞれ代入して，つぎのように求め られる.

$$
\left\{\begin{aligned}
i_{a}(t)= & -e^{-t \alpha} q_{1}\left\{\left(e^{t_{c} \alpha}-e^{t \alpha}\right) F_{l}\left(F_{l}-H \alpha\right)\right. \\
& +\left(e^{\left(t+2 t_{c}\right) \alpha}-e^{\left(2 t+t_{c}\right) \alpha}\right) F_{l}\left(F_{l}+H \alpha\right) \\
& \left.+\left(e^{2 t \alpha}-e^{2 t_{c} \alpha}\right)\left(F_{l}^{2}-H^{2} \alpha^{2}\right)\right\} \\
& \left\{n K\left\{H \alpha+\left(e^{t_{c} \alpha}-1\right) F_{l}\right\} \eta\right\}^{-1} \quad\left(0 \leq t \leq t_{c}\right) \\
i_{b}(t)= & e^{-t \beta}\left(e^{t_{c} \alpha}-1\right)^{2} q_{1} \alpha\left\{\left(e^{\left(t_{c}+2 t_{f}\right) \beta}\right.\right. \\
& \left.-e^{\left(t+2 t_{f}\right) \beta}\right) F_{l}\left(F_{l}-H \beta\right)+\left(e^{\left(t+2 t_{c}\right) \beta}\right. \\
& \left.-e^{\left(2 t+t_{c}\right) \beta}\right) F_{l}\left(F_{l}+H \beta\right)+\left(e^{\left(2 t+t_{f}\right) \beta}-e^{\left(2 t_{c}+t_{f}\right) \beta}\right) \\
& \left.\left(F_{l}^{2}-H^{2} \beta^{2}\right)\right\}\left\{n K\left\{H \alpha+\left(e^{t_{c} \alpha}-1\right) F_{l}\right\}\right. \\
& \left.\beta(\eta-2)\left(e^{t_{c} \beta}-e^{t_{f} \beta}\right)^{2}\right\}^{-1} \quad\left(t_{c} \leq t \leq t_{f}\right)
\end{aligned}\right.
$$

この電流の式を式 (4) に代入して積分すれば, 第 1 項 目より全ジュール熱 $J_{R}$ が決められる. また, 第 2 項 目にある角速度 $\dot{\theta}(t)$ として式 (40) と式 (41) を用いれ ば, クーロン摩摖による損失 $J_{C}$ および粘性摩擦によ る損失 $J_{l}$ もそれぞれ求められる. これらは零交差時間 $t_{c}$ の関数であるので, 散逸エネルギーを最小にする最 適な零交差時間 $t_{c}{ }^{*}$ は, 次式から求められる.

$$
\frac{\partial\left(J_{R}+J_{C}+J_{l}\right)}{\partial t_{c}}=0
$$

低速回転の場合と違って, $J_{R}, J_{C}, J_{l}$ は $t_{c}$ の複雑な関 数になっている. したがって, 最適な零交差時間は簡 単な式によって表現できない。

\section{6. シミュレーション}

シミュレーションは $n=10, K=0.1, \theta_{f}=1, \theta_{0}=0$, $t_{f}=1$ の条件で行われた.

6.1 最適な角速度・電流関数 最適な電流関数, 角速度関数が粘性摩擦力の有無によって受ける影響を $H=1$ の条件のもとで調べる.

効率が $\eta=0.6$ となるクーロン摩擦力だけがある場 合, 最適な零交差時間は式 $(38)$ より $t_{c}{ }^{*}=0.7$ である. 式 (34) の最適な電流関数は, 図 1(a) の上図のように $t=0.7$ で折れ曲がった直線である. それに対応する 角速度関数は, 図 1(a) の下図のように, 前期と後期で それぞれ 2 次係数の異なる完全な 2 次関数である. な お, 効率が $\eta=1$ の場合, $t_{c}{ }^{*}=0.5$ となり, 電流関数 は 1 本の直線になることは容易にわかる.

一方, 図 1(b) は粘性摩擦係数を $F_{l}=2$ とした結果 である. その場合の最適な零交差時間は式 (51) より $t_{c}{ }^{*}=0.852$ となる. それに基づく電流関数は, 式 (50) より図1(b) の上図のように描かれた. 前期と後期の電 流関数は共にもはや直線ではなく曲線となっている. その曲り方は $F_{l}$ の值が大きくなるほど増加する. 式 (9) からわかるように $t=t_{c}^{*}$ で角加速度の值は 0 では 

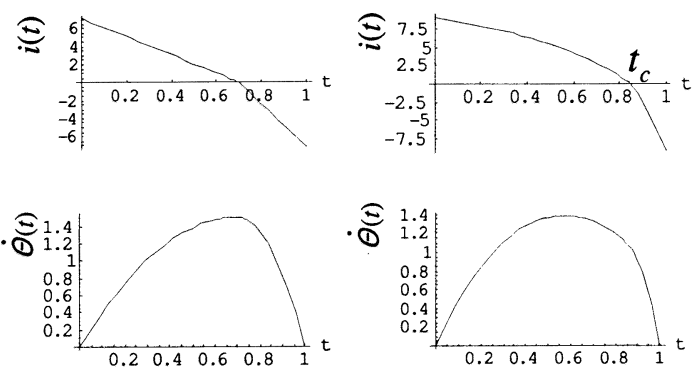

(a) $\quad F_{l}=0$

(b) $\quad F_{l}=2$

Fig. 1 Difference of optimal functions of current $i(t)$ and angular velocity $\dot{\theta}(t)$ between the absence and the presence of viscous friction when $\eta=$ 0.6 .

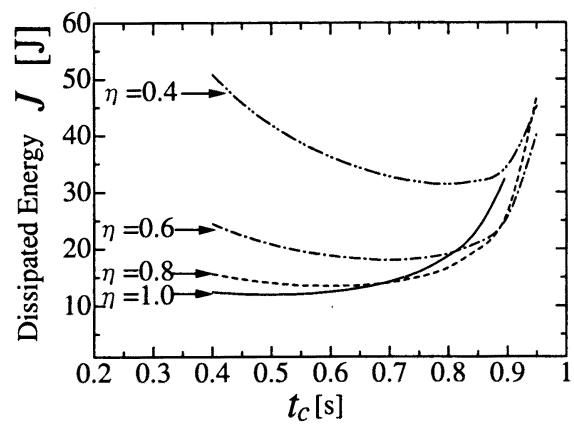

Fig. 2 Dissipated energy $J$ for $t_{c}$ in low speed rotation

ないので, 図 1(b) の角速度関数は, (a) の $F_{l}=0$ の場 合と異なる.

6.2 散逸エネルギーの計算 $\quad H=1$ の条件で クーロン摩擦や粘性摩擦が散逸エネルギーに及ぼす影

\section{響を調べる.}

まず, 減速機の効率が $\eta=0.4,0.6,0.8,1.0$ となる クーロン摩擦のみがある場合を考える. したがって, 式 (35) で示されたジュール熱による損失 $J_{R}$ と式 (36) の摩擦熱による損失 $J_{C}$ に注目する. 零交差時間 $t_{c}$ に 対する全散逸エネルギー $J=J_{R}+J_{C}$ を計算すると, 図 2 のようになった. この図は，いかなる効率 $\eta$ でも, $J$ を最小にする最適な $t_{c}{ }^{*}$ は存在することを示す。一 番上の 2 点鎖線は, $\eta=0.4$ の場合を示し, 最適な零 交差時間が $t_{c}{ }^{*}=0.8[\mathrm{sec}]$, そのときのエネルギーは $J=31.4$ [J] になる. 一番下の実線は, $\eta=1$ の場合を 示し, $t_{c}{ }^{*}=0.5[\mathrm{sec}]$ で最小エネルギーは $J=12[\mathrm{~J}]$ と なる.これらの值はそれぞれ式 (38) と式 (39) に一致 するので, 第 4 章の理論の正当性が証明された.

つぎに, $\eta=0.6$ の条件で, $F_{l}$ を $1,2,3$ と変えて粘

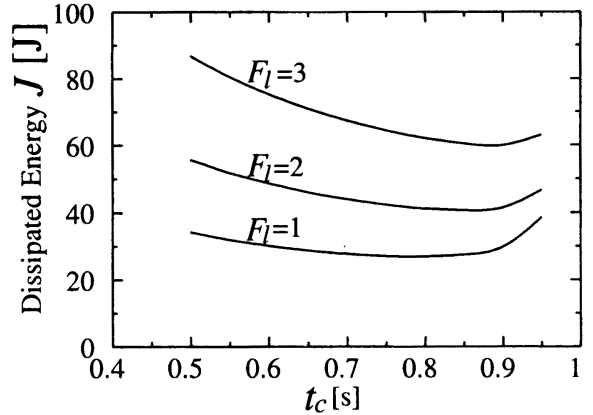

Fig. $3 J$ vs. $t_{c}$ in high speed rotation when $\eta=$ $0.6, H=1$.

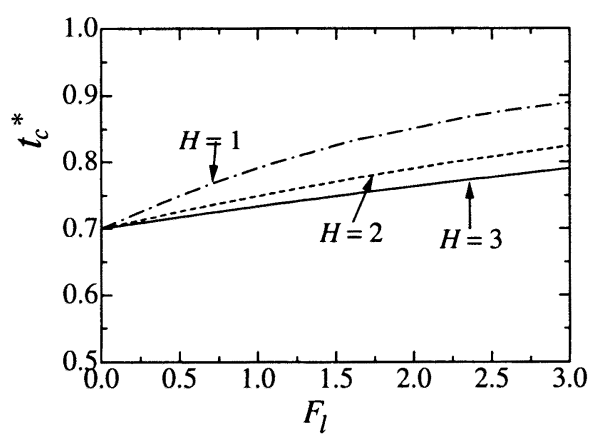

Fig. 4 Tendency of optimal $t_{c}{ }^{*}$ for $F_{l}$ in 3 kinds of inertia when $\eta=0.6$

性摩擦係数の影響を調べる. 図 3 は, それぞれの $F_{l}$ における $t_{c}$ に対する全散逸エネルギーの計算結果で ある.この図から $F_{l}$ が大きくなればなるほど，散逸 エネルギーも増加することがわかる．その原因は粘性 摩擦力によって消耗されるエネルギ一が増えるからで ある. また, どの曲線にも， $J$ を最小にする最適な $t_{c}{ }^{*}$ が存在することがわかる. なお， $H$ を大きくすると, ジュール熱による損失が相対的に増加し，粘性摩擦係 数による曲線の差異は小さくなる.

6.3 最適な零交差時間 効率 $\eta=0.6$ の条件 のもとで, 粘性摩擦係数 $F_{l}$ と慣性モーメント $H$ が最 適な零交差時間 $t_{c}{ }^{*}$ に及ぼす影響を調べた. 図 4 は, $H=1,2,3$ における $F_{l}$ と $t_{c}{ }^{*}$ の関係を調べた結果で ある. $t_{c}{ }^{*}$ は, $H$ に関係なく,$F_{l}$ の低下とともに $0.7[\mathrm{~s}]$ に収束することがわかった. この $t_{c}=0.7[\mathrm{~s}]$ はクーロ ン摩擦力だけがある場合の最適な零交差時間を与える 式 (38) に一致する. また, 同一の粘性摩擦係数におい て慣性モ一メント $H$ の增加につれて $t_{c}{ }^{*}$ が小さくなる ことがわかる. これは, 式 (3) からわかるように, $H$ が大きくなると相対的に $F_{l}$ の影響が小さくなるから 
である.

\section{7. 実験}

実験に用いたモー夕は, 定格出力が $25.4[\mathrm{~W}]$, 電機子 抵抗が $R=5.5[\Omega]$, トルク定数が $K=0.041[\mathrm{~N} \cdot \mathrm{m} / \mathrm{A}]$ である.このモー夕に減速比 $n=14$ の遊星歯車装置 からなる減速機が付けられている.

7.1 パラメータの同定 減速機の摩擦に関する 主なパラメータ $\eta$ と $F_{l}$ を同定する. そのために, 定電 流源で減速機付モータを駆動し, モータ軸に取り付け られたタコメータの角速度信号をディジタルスコープ で観測した. 図 5 と図 6 のそれぞれの上部の波形は, モータに流す矩形波電流を示し, 振幅が $i_{p}= \pm 0.2[\mathrm{~A}]$ と設定されている. それぞれの下部は角速度の波形を 示す.

伝達効率 $\eta$ を測定するために, 低速回転で実験する 必要がある. したがって, 矩形波電流の周期を 0.2 [s] と短くした. 角速度関数は, 電流が正の場合 $F_{l}=0$ と した運動方程式 (7) より, $\dot{\theta}(t)=H^{-1} \eta n K i_{p} t$ と 1 次式 で表される. したがって，その傾き $s_{p}$ は

$$
s_{p}=H^{-1} \eta n K i_{p}
$$

となる. 一方, 電流が負の場合, $F_{l}=0$ とした運動方 程式 (19)より $\dot{\theta}(t)=H^{-1}(2-\eta) n K i_{p} t$ が得られる. 同 様に, その傾きの絶対值 $s_{m}$ は次式となる.

$$
s_{m}=H^{-1}(2-\eta) n K i_{p}
$$

式 (52) と式 (53) の比より, 減速機の効率 $\eta$ は,

$$
\eta=\frac{2 s_{p}}{s_{m}+s_{p}}
$$

と表される.この方法による $\eta$ の計測は， $H$ などの

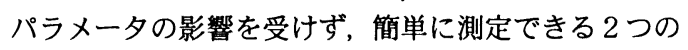
傾斜のみから求められる利点がある. 低速回転実験に おける図 5 の角速度は, 区分的な直線でほぼ近似でき る. その傾きの絶対值は, 電流の正負に応じて異なっ ていることがわかる.これは, 式 (2) のクーロン摩摖 トルクの式が妥当であることを示す. 図 5 から $s_{p}, s_{m}$ を読み取って, 式 (54) から $\eta \approx 0.70$ という值を得た.

図 6 は, 矩形波電流の周期を $2.47[\mathrm{~s}]$ と長くして, 高 速回転を実現させたときの実験結果である. 図の下の 波形は, 角速度 $\dot{\theta}(t)$ を示し, 粘性摩擦力のために一次 遅れ系の応答となっている. この時定数 $T$ は, 式 (7) からわかるように $T=H / F_{l}$ である. 図 6 より測定さ れた時定数 $T \approx 0.4[\mathrm{~s}]$ と, 出力軸から見た慣性モーメ ント $H=0.960 \times 10^{-3}\left[\mathrm{~kg} \cdot \mathrm{m}^{2}\right]$ より, 粘性摩擦係数とし $\tau F_{l} \approx 0.002[\mathrm{~N} \cdot \mathrm{m} \cdot \mathrm{s}]$ と同定した.

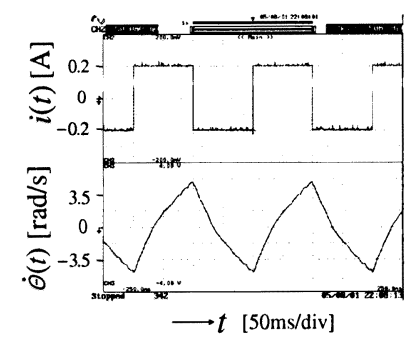

Fig. 5 Driving current $i(t)$ and angular velocity $\dot{\theta}(t)$ in low speed rotation

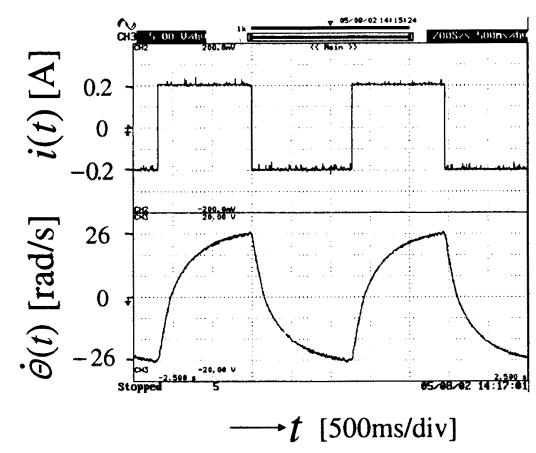

Fig. 6 Driving current $i(t)$ and angular velocity $\dot{\theta}(t)$ in high speed rotation

7.2 実験結果 $\quad \eta \approx 0.70, F_{l} \approx 0.002$ という同 定結果を用いて, $t_{f}=1[\mathrm{~s}], \theta_{f}-\theta_{0}=2 \pi[\mathrm{rad}]$ の条 件下で実験をした. 減速機の出力側に慣性モーメント $H_{L}=2.8 \times 10^{-3}\left[\mathrm{~kg} \cdot \mathrm{m}^{2}\right]$ の円盤を付加して, 入力側を前述 のモータで駆動させた. 駆動系のパラメータを用いて 式 $(51)$ より最適な零交差時間 $t_{c}{ }^{*} \approx 0.72$ を求め, 式 (50)より最適な電流関数と 5.1 節より角速度関数を計 算すると,これらは図 7 に示す波形となった.この最 適な角速度関数を速度フィードバック制御回路に指令 して, 駆動実験を行った. その結果, 図 8 に示す電流 波形が得られ, 理論から得られた図 7 の波形とほぼ一 致した.

図 9 は, 零交差時間 $t_{c}=0.4,0.5,0.6,0.7,0.8,0.9$ に対する消費エネルギー $J$ の測定結果である. この図 は, $J$ を小さくする最適な零交差時間 $t_{c}$ が存在するこ とと, それが理論值 $t_{c}^{*} \approx 0.72$ と概ね整合することを 示す. 図 9 に示す実験結果は, $t_{c}$ に対する $J$ の理論と 傾向が一致したが, その値は理論值に比べて大きかっ た. その理由は, 本論文の理論が減速機の摩擦のみに 注目していて, それを駆動するモー夕自身の摩擦を無 視しているからである. 


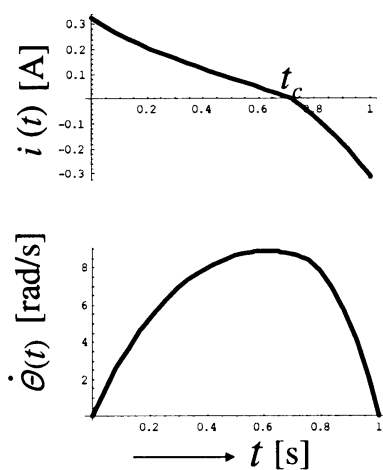

Fig. 7 Theoretical waveforms of current $i(t)$ and angular velocity $\dot{\theta}(t)$

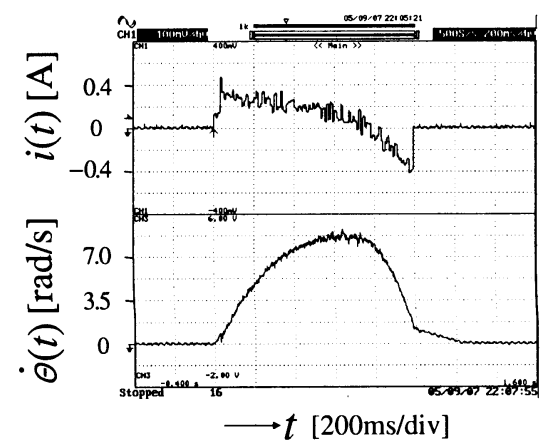

Fig. 8 Experimental waveforms of current $i(t)$ and angular velocity $\dot{\theta}(t)$

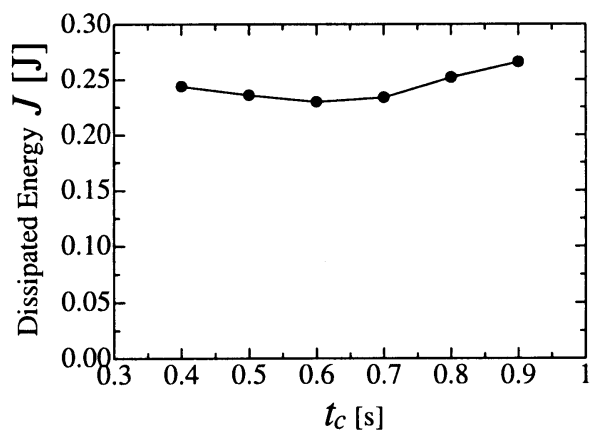

Fig. 9 Experimental results of $J$ for $t_{c}$ when $\theta_{f}=\pi$

\section{8. あとがき}

減速機をもつ角度制御系が始動・停止をする場合に 散逸するエネルギーを最小化する方法を検討した. ま ず, 減速機がもつクーロン摩擦トルクを減速機の効率 とそれを駆動するモータの電流で表した．角度制御系 の回転方向の一定性を仮定して, クーロン摩擦トルク
がモー夕の電流の絶対值に比例する運動方程式を作っ た. クーロン摩擦によるこの非線形性を解決するため に, 電流が正から負への変化する零交差時間 $t_{c}$ を導入 した. この零交差時間 $t_{c}$ を用いることによって, 決め られた動作時間で目標角度に達するために散逸される ジュール熱と摩擦熱を定式化できた．そして，散逸工 ネルギーを最小にする最適な零交差時間 $t_{c}{ }^{*}$ が減速機 の効率の簡単な関数になることを導いた. さらに, 高 速回転時の粘性摩摖が散逸エネルギーに及ぼす影響を 考慮した最適な零交差時間を求める方法を示した.

提案した方法を用いてシミュレーションを行い, 粘 性摩擦係数や慣性モ一メントが最適な零交差時間 $t_{c}{ }^{*}$ に及ぼす影響を調べた，その結果，最適な零交差時間 は粘性摩擦係数の増加とともに大きくなり, その傾向 は慣性モーメントが小さい程大きいことがわかった. 小型のモ一タを用いて基本的な実験をして, クーロン 摩擦トルクがモータの電流の絶対值に比例することを 確認した. また，実験で得られた電流関数，角速度関 数, および零交差時間に対する散逸エネルギーの傾向 は理論とほぼ一致した. しかし, 両者の值には差異が あったので, 今後, モ一タの摩擦も考慮して, 理論と 実験の一致度を高める予定である.

\section{文献}

(1) Takano, M., Techniques for Speed-up of Robot Motion, $T$. of the Society of Instrument and Control Engineers, Vol. 21, No. 12 (1982), pp. 1122-1128.

(2) Funabashi, H., Iwatsuki, N. and Takeda, Y., Selection of DC Motors and Reduction Gears for Robots with Consideration of Energy Consumption, $T$. of the Japan Society of Mechanical Engineers, Series C, Vol. 56, No. 528 (1990), pp. 2179-2186.

(3) Izumi, T., Minimization of Energy Consumption for a Manipulator with Nonlinear Friction in PTP Motion, J. of the Robotics Society of Japan, Vol. 13, No. 8 (1995), pp. 1179-1185.

(4) Izumi, T., Energy and Time Optimal Path Planning of a Horizontally Articulated Manipulator, $P$. of the 2000 Japan-USA Flexible Automation Conference, (2000).

(5) Yokose, Y. and Izumi, T., Minimization of Dissipated Energy of a Manipulator with Coulomb Friction using the GA Increasing the Calculated Genetic Information Dynamically, $T$. of the Japan Society for Computational Engineering and Science, Vol. 7, (2005), pp. 95-102.

(6) Naruse, C., Friction loss of Spur Gear, Science of machine, Vol. 49, No. 7 (1997), pp. 751-761.

(7) Katou, K., Applied Optimal Control, (1993), University of Tokyo Press 